\title{
Negotiation Processes as Success Factors in Supply Chain Transactions
}

\author{
Alexander Stelzer PhD Cand. \\ University of Latvia, Riga
}

\begin{abstract}
The topics raw materials, waste and energy will be the top economic issues of the future, or influence and affect all other subjects (human resources, culture, society,...); all combined with technology, IT and Tech Communication. The shortage of raw materials is one of the central issues in the future perspective and this fact is already influencing the relationship between buyer, producer and supplier. and producers respect to the procurement of raw materials, goods and products are examined specifically in terms of their economic and psychological satisfaction.
\end{abstract}

Keywords: Negotiation Processes as Success Factors in Supply Chain Transactions

\section{Introduction}

In this title and thesissummary follows the point, that world population is steadily increasing, yet raw materials, especially consumer goods, are distributed unequally and raw material prices keep growing at a disproportionate rate. ${ }^{1} \mathrm{~A}$ large share of the world population has no access to adequate consumer supplies or simply cannot afford basic goods since their prices keep rising beyond their reach. It simply cannot be that so many countries have no access to global commodities. ${ }^{2}$ Humans cannot tolerate that an all-powerful minority controls the distribution of basic commodities and is profiteering at the expense of the less fortunate majority. ${ }^{3}$ Procurement markets needs more knowledge and tools for both the procurement and the allocation of goods, for a common and transparent review, as well as analysis tools with regard to the future procurement situation, because if people do not get enough consumer goods and commodities, they are technically deprived of one of their basic human rights. ${ }^{4}$ In consequence they will lack ambition for any meaningful development and they will further lose faith in ideals and standards. ${ }^{5}$ The UN Food and Agriculture Organization (FAO) in early June 2010, in their semi-annual "Food Outlook", recognize that the cost of consumer goods and commodities are rising, particularly in the world's poorest countries. Scarcitiesin the supply chain transactions and the daily procurement of supply chain transactions are certainly topics that should concern us all, since the consumption of all kinds of all articels of the human needs and therefore concerns us all. ${ }^{6}$ This sector has undergone drastic changes over the last couple of years, both locally as well as globally. Humans have to clearly distinguish, however, among end consumer purchases, the procurement of commodities by the wholesale trade, the distribution of goods through dealers and distributors, all of which can be operated in different ways and their negotiation process in the supply chain transactions. Likewise, the role of the producer and the role of the supplier respectively will be addressed in chapter two, since their current roles have also undergone dramatic changes, regionally, nationally and globally. ${ }^{7}$ The supply chain transactions of commodity resources, in particular consumer goods, is not the same for everyone worldwide. Trading companies have begun to notice the changes and have thus set out new intern

\footnotetext{
1 "Warnung vor globaler Nahrungsmittelkrise [Warning against global food crisis] - news.ORF.at," http://orf.at/stories/2008198/2008197/ (accessed May 8, 2011).

2 Miles Kahler, "Rising Powers and Global Governance: Reforming a Resilient Status Quo," Journal of International Affairs 89, no. 3 (2013): 711-29.

${ }^{3}$ Lorenzo Cotula et al., "Land Grab or Development Opportunity - International Land Deals in Africa Land Grab or Development Opportunity," Journal for the Theory of Ordered Sets and Its Applications 36, no. 8 (2009): 130.

4 United Nations, World Hunger Series: Hunger and Markets, Analysis - World Food Programme, 2009.

${ }^{5}$ Parts of this chapter have been published in my Journalarticles or have been presented during my conference participations

${ }^{6}$ various, "OECD-FAO AGRICULTURAL OUTLOOK 2010-2019 HIGHLIGHTS," OECD-FAO Agricultural Outlook, 2010.

7 Trommsdorff Volker, "Handelsforschung 1988: Schwerpunktthema: Standortfragen [Trade Research 1988: Focus on the Topic of Location Surveys]," 2013, 276. pp.10
} 
targets for the annual Negotiation and Partner Meetings between buyers and suppliers: ${ }^{1}$ The demands with regard to the supply chain transactions are as follows: product prices must drop, quantities (or: output) must increase in the following year. The reality in trade shows that individual product quantities have remained stagnant and only grown as regards product range, while prices keep steadily rising due to increasing, direct and indirect stringency.

Decade-long and familiar patterns have become outmoded, so stress scenarios affecting all parties involved in negotiations and annual appraisal meetings have become a regular feature in natural consequence.

The familiar culture of conversation between the negotiation parties have changed or rather must change - a common set of goals must be the natural consequence, so as to ensure supplies to the utmost satisfaction of all parties concerned.

There are no instruments or tools for future-oriented negotiations, or that is to say they are still in a developing phase and the data generated therefrom is usually past-oriented or present-oriented.

The object of the research deals with the evaluation and analysis of direct and indirect factors influencing the negotiations between procurers and suppliers in the supply chain transactions. ${ }^{2}$ On the basis of the "Efficiency Model of Negotiation", it will be reviewed how negotiations between purchasers and sellers should be conducted on an optimal level. For this, the Harvard Negotiation Project is applied in a query to analyse the derived ideal negotiating situation.

The subject of the research is to analyse the procurers and suppliers, who are evaluated specifically in terms of their economic and psychological efficiency and if it is possible to achieve equal economical and mental satisfaction for all parties involved in the negotiating process, all along, there has usually been a loser, sometimes a winner, at the end of negotiations. ${ }^{3}$

The Aim of the thesis is to look at the current situation and draw conclusions in order to improve relations and cooperation among all parties involved. If we could resolve the "fronts" between "the procurement side" and "the supply side" and convert these 'hostile stand-offs' into mutually beneficial cooperation through more trust and transparency, it would help the entire cycle. ${ }^{4}$ Evaluation of the procurement market and sources of supply in view of the new approach, direct and indirect influences on trust and transparency during negotiations and the effects of the current shortage rate. ${ }^{5}$ Procurement policies and practices of today will not work in the future, because already experiencing shortages and in consequence drastic cutbacks in purchasing volumes. ${ }^{6}$

Actuality of the research is that Trading Companies have begun to notice changes in the efficiency of negotiation process in supply chain transactions and have thus set out targets. The problemfield is that the usual negotiation processes are not longer working in a satisfactoring way and the procurement markets and their negotiators are searching for new forms of negotiation processes in the questions of the supply chain transactions. ${ }^{7}$ Here comes the input of this study, which shows a new form of negotiation, empirically evaluated in a postfactum selfreported field study and documented in the "Efficiency Model of Negotiation". The main themes for the supply chain transactions in the future are, that the interplay in the questions

\footnotetext{
${ }^{1}$ Robert B. Handfield and Christian Bechtel, "The Role of Trust and Relationship Structure in Improving Supply Chain Responsiveness," Industrial Marketing Management 31, no. 4 (July 2002): 367-82.

2 Stefan Seuring and Martin Müller, "From a Literature Review to a Conceptual Framework for Sustainable Supply Chain Management," Journal of Cleaner Production 16, no. 15 (October 2008): 1699-1710.

3 Steve New, "The Transparent Supply Chain," Harvard Business Review October, no. October 2010 (2010).

${ }^{4}$ Frederik Zachariassen, "Negotiation Strategies in Supply Chain Management," ed. Gyongyi Kovacs, International Journal of Physical Distribution \& Logistics Management 38, no. 10 (November 7, 2008): 764-81.

${ }^{5}$ Kevin Burgess, Prakash J. Singh, and Rana Koroglu, "Supply Chain Management: A Structured Literature Review and Implications for Future Research," ed. Paul D. Cousins. Co-Editors: Benn Lawson, International Journal of Operations \& Production Management 26 , no. 7 (July 11, 2006): 703-29.

${ }^{6}$ Henk Akkermans, Paul Bogerd, and Jan van Doremalen, "Travail, Transparency and Trust: A Case Study of Computer-Supported Collaborative Supply Chain Planning in High-Tech Electronics," European Journal of Operational Research 153, no. 2 (March 2004): 445-56.

${ }^{7}$ Peter Schnedlitz et al., "European Retail Research," ed. Thomas.rudolph@unisg.ch Dirk Morschett, University of Fribourg, Switzerland, Dirk.morschett@unifr.chThomas Rudolph, University of St. Gallen, Switzerland et al., Journal of Retail Research 24, no. II (2010): 205.
} 
of procurement is the completely changing and for that reasons there different and warious reasons that this thesis will evaluate. ${ }^{1}$

The research question of this thesis deals with the analysis of direct and indirect factors influencing the negotiations between procurers and suppliers in the in the world of trade and wholesale market. ${ }^{2}$

It is requested on the basis of a structural equation model "Efficiency Model of Negotiations", such as the negotiation processes between purchasers and sellers in the optimal case expire have and how to create an optimal situation and a common result in supply chain transactions. ${ }^{3} 4$

These changes mean that the procurement market is emerging in accordance with new rules for supply chain transactions and that this places then volved negotiation parties in new negotiating situations and their processes.

The interaction between procurers and suppliers is analysed specifically in terms of their economic and social-psychological efficiency. Stress scenarios affecting all parties involved in negotiations and annual appraisal meetings have become a regular feature in natural consequence. ${ }^{5}$

There is no known study with future-oriented negotiation processes in supply chain transactions, or that is to say they are still in a developing phase and the data generated therefrom is usually past-oriented or present-oriented. ${ }^{6}$ The procurement market and the supply chain transactions needs more knowledge and tools for the procurement and allocation issues.

For a common and transparent review and also analysis tools in regard to the future procurement situation, a new tool for knowledge in supply chain transactions is the "Efficiency Model of Negotiation" pictured in this thesis.

Purpose of the research is for these reasons that the author of this thesis has been posing the question what the future of trade in general and procurement of food products in particular is going to be like, or rather how suppliers and sales staff are going to co-operate and which areas still leave room for improvement. ${ }^{7}$ Co-operation between trade and consumers manifests itself in the sales market which strongly revolves around marketing and strategic brand management. Cooperation between trade (wholesale and retail) and suppliers is strongly rooted in the negotiation processes. ${ }^{8}$ Which products are to be marketed and sold and are they worth ordering and if so, at what prices and quality and in what quantity. At this point we are addressing the doctrine of efficiency in negotiation theories, focal points this dissertation is centred on. ${ }^{9}$ What are the procurement procedures among the various structures and organisations like, and what can be done in an effort to improve and optimize these interactive processes between wholesalers and suppliers, producers, middlemen and other trade partners. And how can we secure efficient and sustainable long-term supplies in the future. ${ }^{10}$

\footnotetext{
${ }_{1}^{1}$ Peter Voithofer Kerstin Hölzl, Karin Bachinger, "Analyse Des Österreichischen Großhandels Bedeutung Und Entwicklung [Analysis of the Austrian Wholesale Importance and Development] - Austrian Institute for SME Research," Publication of Austrian Chamber of Economic Study (Vienna, 2011). pp.3

2 OECD - Food and Agricultural Organization of the United Nations, "OECD-FAO Agricultural Outlook, 2014-2023," OECD-FAO Agricultural Outlook, 2014, 329.

${ }^{3}$ Sarris, Conforti, and Prakash, "The Use of Organized Commodity Markets to Manage Food Import Price Instability and Risk."

${ }_{4}^{4}$ Prof. Dr. Peter Schnedlitz, "Der Handel Im Umbruch [The Trade in Upheaval]," Journal Für Markenartikel Und Den Modernen Einzelhandel Jahrgang 4 (2015): 27-30.

5 Josef Zelger and Andreas Oberprantacher, "Processing of Verbal Data and Knowledge Representation by GABEK®-WinRelan®," Qualitative Social Research Forum 3, no. 2 (2002).

${ }^{6}$ Mike Burnette John Bell PhD, Diane Mollenkopf PhD, J. Scott Meline, "Research Paper of Creating a Transparent Supply Chain" (Hallam University, Knoxville, US, 2016).

${ }^{7}$ Ronald H Ballou, Stephen M Gilbert, and Ashok Mukherjee, "New Managerial Challenges from Supply Chain Opportunities," Industrial Marketing Management 29, no. 1 (January 2000): 7-18.

${ }^{8}$ M. Esmaeili and P. Zeephongsekul, "Seller-buyer Models of Supply Chain Management with an Asymmetric Information Structure," International Journal of Production Economics 123, no. 1 (January 2010): 146-54.

${ }^{9}$ Richard C. Lamming et al., "Transparency in Supply Relationships: Concept and Practice," The Journal of Supply Chain Management 37, no. 4 (September 1, 2001): 4-10.
}

${ }^{10}$ Henry Mintzberg and Frances Westley, "Decision Making : It 'S Not What You Think," MIT Sloan Management Review 42, no. 3 (2001): 89-94. 
The task of the research is in this study to examine and illustrate the processes among negotiation parties and negotiators and it also look into how and what common interests meet, if single individuals attempt to reach a compromise and further elaborate on the question as to when a compromise reached may actually be adopted as a commonly reached compromise that constitutes a fair compromise which can be positively received and accepted by all parties involved in supply chain transactions. Is there such a thing as a positive compromise and if so when can we talk about efficiency. ${ }^{1}$ At this point we obviously have to ask all the same if there is such a thing as a negative compromise and if so, when or in what situation are we faced with a negative compromise. Also, how does a compromise affect the negotiation parties, and is everyone equally affected or is there such a thing perhaps as a single/individual compromise. ${ }^{2}$ "There's renewed need for mutual trust and transparency. The major question that begs to be answered is: where should it come from. At this point in particular the importance of economic science truly becomes evident. It is the responsibility of economic science to develop credible explanatory models for existing problems, as well as a new overview, one that is capable of restoring trust and transparency in the economic mechanisms to ensure that people will, in their own best interest, feel remotivated to do business again which will in turn give fresh impetus to the micro- and macroeconomic dynamics. At present, no solutions have been found as yet, and it will probably require a fair amount of effort of being willing to ,forgive and forget', before renewed confidence and trust can be built. Nonetheless, we should not allow ourselves to be discouraged. All it takes in the long run is trust and transparency in the sustainability of human creativity and the ability for continuous renewal. Already Alois Schumpeter realized that there are good reasons to believe that this is quite possible: "We are no closer to exhausting the endless possibilities today than we were during the Stone Age." ${ }^{3}$ As can be seen from previous sentences, synergies among people in negotiations in supply chain transactions have been addressed. ${ }^{4}$ Various forms of negotiations have also been dealt with in detail, what is left to be addressed is the topic of "trust and transparency", which basically covers and explains the ideal scenario of negotiations. That way the theoretical background has been created against which we can now focus on the approach, since all previously covered topics are reflected in this paper.

The main hypothesis of research is formulated as "The scrutiny and analysis of annual negotiations between procurers and suppliers for supply chain transactions. How will complete trust and transparency in negotiation processes and be perceived by all negotiating parties with regard to their economic and social-psychological efficiencies."

MetaH. The more closely negotiations comply with the variables of the model of the "Harvard Negotiation Project" and the more "Degree of Trust and Transparency" are ensured, the higher the economic and social-psychological efficiencies will be.

H1. The more strictly the Harvard Concept is applied in conducting the negotiations, the higher the efficiency of the outcome of the negotiations.

$\mathrm{H} 2$. The more trust and transparently the negotiations are conducted, the higher the efficiency of the outcome of the negotiations.

\footnotetext{
${ }^{1}$ Rolf Weiber and Daniel Mühlhaus, Strukturgleichungsmodellierung [Structuralequationmodeling] (Springer Verlag Berlin Heidelberg, 2010). p. 7

2 Jens Vollmar and Isabella Hoffend Roman Becker, Macht Des Vertrauens [Power of Trust], ed. Schweiz Universitat St.Gallen (Springer Fachmedien Wiesbaden, 2013). Vorwort: Prof. Dr. Peter Leibfried, KPMG- Professor an der Universität St. Gallen
}

${ }^{3}$ Amelia S. Carr and Larry R. Smeltzer, "The Relationship of Strategic Purchasing to Supply Chain Management," European Journal of Purchasing \& Supply Management 5, no. 1 (March 1999): 43-51.

${ }^{4}$ By the Author 


\section{EFFICIENCY MODEL OF NEGOTIATION}

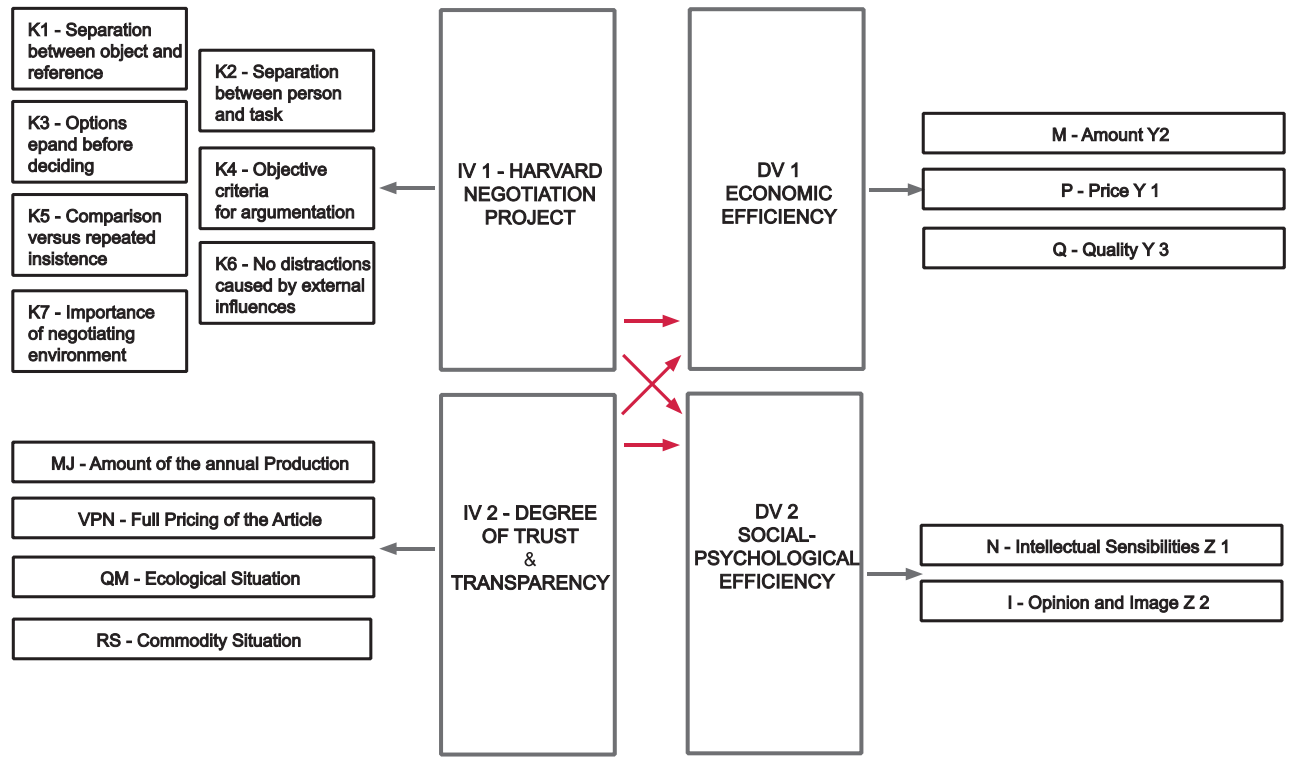

Figure 1 - Research Design - „Efficiency Model of Negotiation“

Source: 1

Theses presented to defend with the creation of a model that investigates empirically, both the economic and the psychosocial factors of efficiency in negotiation processes between buyers (procurers) and suppliers (producers) in supply chain transactions. In particular, it examines the economic and mental satisfaction in the in the negotiation processes for efficient supply chain transactions. It examines how trust and transparency in negotiations and at annual meetings can achieve a satisfactory result for both negotiating parties.

The novelties of the research and the authors research question deals with the following topics:

This thesis deals with research question of analysis of direct and indirect factors influencing the interaction between procurers and suppliers in the trade and wholesale market. It is requested on the basis of a structural equation model, such as the negotiations between purchasers and sellers in the optimal case expire have and how to create an optimal situation and a common result. For this, the Harvard Negotiation Project is used to query the derived ideal negotiation situation. Respectively the focus of this study on the aspect: The interaction between procurers and suppliers is analyzed specifically in terms of their economic and social-psychological efficiencies.

On the basis of a structural equation model "Efficiency Model of Negotiation", it will be reviewed how negotiations between purchasers and sellers should be conducted on an optimal level. How are optimal negotiation processes created and how can negotiations become conducive towards a common result in supply chain transactions.

${ }^{1}$ Benita M. Beamon, "Measuring Supply Chain Performance," International Journal of Operations \& Production Management 19, no. 3 (March 11, 1999): 275-92. 
The procurement market and so the supply chain transactions needs more knowledge and tools for the procurement and allocation issues, for a common and transparent review and also analysis tools in regard to the future procurement situation. A new Model for Negotiation processes in Supply Chain Transactions is as the "Efficiency Model of Negotiation" pictured in this thesis. The "Efficience Model of Negotiations" developed by the author is the most comprehensive model in the area of negotiation processes, combining with "Degree of Trust and Transparency" in one model, to explain the impacts of economic and social-psychological efficiency as result of negotiations in supply chain transactions.

In this thesis it is identify that trust and transparency strongly impacts economic and mental outputs positively, if it is part of the negotiation processes in supply chain transactions and annuel and all negotiations between the negotiation parties. Prior research was mainly focusing on negotiation processes combined with trust and transparency and their impact on performance in combination with the Harward Negotiation Project. In this form and complexity this has not yet been considered - trust in the negotiation of the parties among themselves and transaprency for the clear depiction of all supply chain transactions and all processes and thus also full transparency to the consumers. The intensive study was carried out by evaluating journals, research papers, scientific reports, important books and empirically in the form of a field study.

The key contribution of the author to science is that the form and the prescription of the negotiations have a great influence on how the parties behave in the negotiations of the supply chain transactions and whether prescriptions are implemented and lived. This model developed here, together with the observed data, is fundamentally different from the previous evaluations, as the author has identified in an in-depth analysis. Past negotiation practices with trust and transparency methods have a great impact on the various efficiencies of the negotiating parties. Most authors have focused on established practices and strategies, such as the in this thesis presented Harvard Negotiation Project, and analyzed the impact of negotiations primarily on their impact on economic efficiency, such as price, quantity and quality, or their monetary competitiveness. This study, on the other hand, analyzes the impact of negotiation processes in supply chain transactions, taking into account trust and transparency, their economic and social-psychological efficiencies of the parties after negotiations. Statistical analysis in the form of a field study supports the view that trust and transparency has a clear impact on the economic and mental efficiencies of negotiation results. But this form of negotiation through trust and transparency requires a clear support of all negotiating parties to be successful and efficient.

The author's work shows that a higher level of trust and transparency in negotiation processes in supply chain transactions maturity leads to higher efficiency in form of economic efficiency - price, quantity, quality and socio-psychological efficiency - intellectual sensibilities, opinion and image by both sides of negotaiation parties the suppliers and buyers.

Research Methods used scientific databases, research reports and papers and an empirical research investigation by interviews in a postfactum field study per selfreporting - cause-effect relationship - negotiation processes with empirical relining, for a discussion about the efficiency degrees, depending on trust and transparency in the communication skills in discussions between two control groups buyers (procurers) and suppliers (producers). It also should be mentioned that the questionnaire has been carried out completely anonymous. Questionnaire to establish the level of efficiencies, depending on trust and transparency and the communication skills in discussions between buyer side and supplier side in supply chain transactions. Investigations through interviews carried out in a field study the negotiation processes with empirical relining with real negotiators from the buyer side and the supplier side in supply chain transactions and the situations of real annual meetings in the years 2015 and 2016 as a postfactum selfreporting study, so measurement of real and past events and facts is given. The feasibility of measurability was thus ensured, that usually to measure efficiency is not the want, but the negotiation success, but what is success in negotiations, because there is no objective unity for success. This study measures efficiency, because we measure the degree of own goal achievement questionnaire, which target the two parties of the negotiations had set themselves and which target was reached at the end. In this way, we define the goal and the result, which results in a value that identifies the path, and therefore we measure efficiency in relation to the fact that negotiation is not objectively measurable or objectivizable. ${ }^{1}$

By sending invitations for interviews in the years 2015 and 2016 to 500 decision makers in the germanspeaking area of wholesalers and tradinghouses with a retourn of real interviews of total 218 , partial 61 , fully 157 completed questionnaires

\footnotetext{
1 Great East (Büyük Doğu) is a literary journal, published by Necip Fazil Kisakurek, in different periods between 1943 and1978. The journal with an Islamist point of view included those many of which were close friends of Necip Fazil and housed the famous intellectuals of the period. The journal, led by Necip Fazil, attracted the reaction of the ruling power both in the single party period and DP government, with the violent opposition it carried out.
} 
remained at our disposal for assessment, which, in a possible number of 500 addresses, means a positive and usable response rate of 31.4 percent. In sum 50 questions, so the collection ran over real and virtual questionnaires, which were recorded on the system LimeSurvey.org and also been prepared for the calculation in IBM SPSS Statistics, Version 22.

Introduction and explanation of the issues - Respondents will be explained in a short text, which content and which target this survey has $G Q$ - General questions, where in this part of demographic and personal data were queried with 13 questions and 3 open additional questions and here the distinction between buyers and sales has been made; here was also queried whether it is the buyer or supplier. DV - Dependent variables, where the dependent variables were queried with 10 questions and it was discussed whether the respondents perceived by negotiations in the economic and socialpsychological efficiencies improve, or how they would evaluate the outcome of negotiations. IDV - Independent variables, where the dependent variables were monitored via 24 main questions and the dependent variables of the groups "Harvard Negotiation Project" and "Degree of Trust and Transparency" were discussed and monitored here and this part had the aim how Harvard Negotiation Project is previously installed in negotiations, or been practiced and applied and this part had the aim how Trust and Transparency concept is previously installed in negotiations, or been practiced and applied. Which negotiation technique with respect to mutual trust and transparency must be applied in future to optimize the negotiating process between the two control groups "givers and takers" - "buyers and suppliers" due to the increasingly difficult procurement scenario. What form of negotiation needs to be created, in order to improve the situation and to achieve the highest possible degree of satisfaction in both an economic and a mental sense. What changed the level of disclosure and transparency of all proceedings variables and an open discussion (full transparency) the design of negotiations in respect to economic satisfaction as price, quantity, quality or the social-psychological efficiency regarding fears, nervousness, satisfaction level, the impact and image of the acquirer regarding trade outwards.

Main results describe that the procurement market needs more knowledge and tools for both the procurement and the allocation of goods, for a common and transparent review, as well as analysis tools with regard to the future procurement situation. Total transparency of prices, amount and quality must be ensured in an approach to meet everyone's interests and expectations and thus consequently raise the economic and social-pychological efficiencies of all parties. If we could resolve the "fronts" between purchasers, suppliers and producers and instead promote co-operation through improved trust and transparency during the negotiating process, this would help the entire cycle. This scientific study has resulted in an extension of the Harvard concept by adding trust and transparency as an additional key factor for economic and mental satisfaction for all negotiating parties. Full trust and transparency applied in an open and fair discussion unarguably has a positive impact on the conduct and outcome of negotiations in respect of the economic satisfaction through contentedness with price, quantity, quality, as well as the psychological satisfaction.

\section{List of References}

[1] Akkermans, Henk, Paul Bogerd, and Jan van Doremalen. "Travail, Transparency and Trust: A Case Study of Computer-Supported Collaborative Supply Chain Planning in High-Tech Electronics." European Journal of Operational Research 153, no. 2 (March 2004): 445-56.

[2] Ballou, Ronald H, Stephen M Gilbert, and Ashok Mukherjee. "New Managerial Challenges from Supply Chain Opportunities." Industrial Marketing Management 29, no. 1 (January 2000): 7-18.

[3] Beamon, Benita M. "Measuring Supply Chain Performance." International Journal of Operations \& Production Management 19, no. 3 (March 11, 1999): 275-92.

[4] Burgess, Kevin, Prakash J. Singh, and Rana Koroglu. "Supply Chain Management: A Structured Literature Review and Implications for Future Research." Edited by Paul D. Cousins. Co-Editors: Benn Lawson. International Journal of Operations \& Production Management 26, no. 7 (July 11, 2006): 703-29.

[5] Carr, Amelia S., and Larry R. Smeltzer. "The Relationship of Strategic Purchasing to Supply Chain Management." European Journal of Purchasing \& Supply Management 5, no. 1 (March 1999): 43-51.

[6] Cotula, Lorenzo, Sonja Vermeulen, Rebeca Leonard, and James Keeley. "Land Grab or Development Opportunity - International Land Deals in Africa Land Grab or Development Opportunity." Journal for the Theory of Ordered Sets and Its Applications 36, no. 8 (2009): 130.

[7] Esmaeili, M., and P. Zeephongsekul. "Seller-buyer Models of Supply Chain Management with an Asymmetric Information Structure." International Journal of Production Economics 123, no. 1 (January 2010): 146-54.

[8] Handfield, Robert B., and Christian Bechtel. "The Role of Trust and Relationship Structure in Improving Supply Chain Responsiveness." Industrial Marketing Management 31, no. 4 (July 2002): 367-82. 
[9] John Bell PhD, Diane Mollenkopf PhD, J. Scott Meline, Mike Burnette. "Research Paper of Creating a Transparent Supply Chain." Hallam University, Knoxville, US, 2016.

[10] Kahler, Miles. "Rising Powers and Global Governance: Reforming a Resilient Status Quo." Journal of International Affairs 89, no. 3 (2013): 711-29.

[11] Kerstin Hölzl, Karin Bachinger, Peter Voithofer. "Analyse Des Österreichischen Großhandels Bedeutung Und Entwicklung [Analysis of the Austrian Wholesale Importance and Development] - Austrian Institute for SME Research." Publication of Austrian Chamber of Economic Study. Vienna, 2011.

[12] Lamming, Richard C., Nigel D. Caldwell, Deborah A. Harrison, and Wendy Phillips. "Transparency in Supply Relationships: Concept and Practice." The Journal of Supply Chain Management 37, no. 4 (September 1, 2001): 4-10.

[13] Mintzberg, Henry, and Frances Westley. "Decision Making : It ' S Not What You Think." MIT Sloan Management Review 42, no. 3 (2001): 89-94.

[14] OECD - Food and Agricultural Organization of the United Nations. "OECD-FAO Agricultural Outlook, 20142023." OECD-FAO Agricultural Outlook, 2014, 329.

[15] Sarris, Alexander, Piero Conforti, and Adam Prakash. "The Use of Organized Commodity Markets to Manage Food Import Price Instability and Risk." Journal for Agricultural Economics 42, no. 1 (2011): 47-64.

[16] Schnedlitz, Peter, Dirk Morschett, Thomas Rudolph, and Hanna Schramm-klein. "European Retail Research." Edited by Thomas.rudolph@unisg.ch Dirk Morschett, University of Fribourg, Switzerland, Dirk.morschett@unifr.chThomas Rudolph, University of St. Gallen, Switzerland, Peter.schnedlitz@wu.ac.at Peter Schnedlitz, Vienna University of Economics and Business, Austria, Schramm-klein@marketing.unisiegen.de Hanna Schramm-Klein, Siegen University, Germany, and B.swoboda@uni-trier.de Bernhard Swoboda, University of Trier, Germany. Journal of Retail Research 24, no. II (2010): 205.

[17] Schnedlitz, Prof. Dr. Peter. "Der Handel Im Umbruch [The Trade in Upheaval]." Journal Für Markenartikel Und Den Modernen Einzelhandel Jahrgang 4 (2015): 27-30.

[18] Seuring, Stefan, and Martin Müller. "From a Literature Review to a Conceptual Framework for Sustainable Supply Chain Management." Journal of Cleaner Production 16, no. 15 (October 2008): 1699-1710.

[19] Steve New. "The Transparent Supply Chain." Harvard Business Review October, no. October 2010 (2010).

[20] United Nations. World Hunger Series: Hunger and Markets. Analysis - World Food Programme, 2009.

[21] various. "OECD-FAO AGRICULTURAL OUTLOOK 2010-2019 HIGHLIGHTS." OECD-FAO Agricultural Outlook, 2010.

[22] Volker, Trommsdorff. "Handelsforschung 1988: Schwerpunktthema: Standortfragen [Trade Research 1988: Focus on the Topic of Location Surveys]," 2013, 276.

[23] Vollmar, Jens, and Isabella Hoffend Roman Becker. Macht Des Vertrauens [Power of Trust]. Edited by Schweiz Universitat St.Gallen. Springer Fachmedien Wiesbaden, 2013.

[24] Weiber, Rolf, and Daniel Mühlhaus. Strukturgleichungsmodellierung [Structuralequationmodeling]. Springer Verlag Berlin Heidelberg, 2010.

[25] Zachariassen, Frederik. "Negotiation Strategies in Supply Chain Management." Edited by Gyongyi Kovacs. International Journal of Physical Distribution \& Logistics Management 38, no. 10 (November 7, 2008): 764-81.

[26] Zelger, Josef, and Andreas Oberprantacher. "Processing of Verbal Data and Knowledge Representation by GABEK@-WinRelan®." Qualitative Social Research Forum 3, no. 2 (2002). 